\title{
Pastorale implikasies van die liggaam/denke verbintenis
}

W Coetzer

(Noordwes-Universiteit, Potchefstroom)

\section{ABSTRACT}

\section{Pastoral implications of the mind/body connection}

Against the background of the body/mind connection the focus is firstly on the Biblical view of man as an unfragmented unity. Secondly the emphasis is on the historical roots of the so called biopsychosocial model that is replacing the traditional biophysical method. Furthermore, the focus is also placed on the possibility of physical problems as the result of unresolved emotions; the immune system as an important link within the body/mind connection; critical life changes; the role of genetics as well as important decisions of the will; social support and loneliness; and, the therapeutical value of writing or verbalization. In conclusion the emphasis is put on the pastoral implications of all the above mentioned factors and a plea is made for the inclusion of the pastoral/spiritual dimension in the biospychosocial model. This will lead to a fully multidisciplinary approach in the counseling of the traumatized and/or emotionally wounded person.

\section{DIE FOKUS VAN HIERDIE ARTIKEL}

In hierdie artikel word die volgende probleemstelling ondersoek: Wat is die moontlike pastorale implikasies van die liggaam/denke verbintenis? Teen hierdie agtergrond word daar vervolgens gelet op die historiese aanloop tot die vestiging van die sogenaamde biopsigososiale model. Die vertrekpunte van hierdie model word bespreek en ten slotte word die pastorale implikasies wat hieruit voortspruit aan die orde gestel. Betreffende metodologie is die vertrekpunt in hierdie artikel vanuit 'n psigologies-georiënteerde pastorale benadering.

\section{EPISTEMOLOGIESE VERTREKPUNT}

As basiese vertrekpunt vir hierdie artikel dien die algemene Bybelse uitgangspunt met betrekking tot die eenheid van gees, siel en liggaam by die mens. Hierdie aspek word veral treffend geïllustreer deur Jesus Christus se hantering van mense se behoeftes in die Evangelies. Een van die genesingsterme wat in hierdie verband baie 
algemeen voorkom en wat as voorbeeld gebruik sou kon word, is sõzõ (vgl. Luk 7:50; 8:48 en 18:42). Louw en Nida (1988 vol 2:240) plaas die betekenisse van hierdie term binne die volgende drie semantiese velde:

- Rescue: to rescue from danger and to restore to a former state of safety and well being.

- Save: to cause someone to experience divine salvation.

- Heal: to cause someone to become well again after having been sick.

In hierdie een enkele term is daar dus drie dimensies ter sprake te wete a) fisiese redding uit gevaar; b) geestelike verlossing, en c) fisiese genesing. Redding dui dus op meer as net fisiese genesing en ons kan gevolglik sê dat dit hier gaan om heil en verlossing in sy breedste en diepste Bybelse sin.

Binne hierdie selfde verband is dit verder belangrik om te let op die feit dat by die genesings wat deur Jesus verrig is, die term sõzõ nêrens slegs van toepassing is op 'n enkele ledemaat van die betrokke persoon se liggaam nie, maar altyd op hierdie mens in sy/haar totaliteit. Hierdie aspek word veral baie duidelik geïllustreer deur Jesus se uitspraak, “Jou geloof het jou gered (sõzõ)". Hierdie uitspraak word soms deur Hom gebruik in gevalle waar daar ' $n$ fisiese genesing plaasgevind het (byvoorbeeld die vrou wat aan bloedvloeiing gely het in Luk 8:48), sowel as in gevalle waar iemand geestelike verlossing ervaar het (byvoorbeeld die vrou wat op owerspel betrap is in Luk 7:50). Wanneer daar aan iemand gesê is, "Jou geloof het jou gered (sõzõ)", is die implikasie dus dat iets wat op die geestelike dimensie plaasgevind het (geloof) ' $n$ impak op die fisiese dimensie (genesing) tot gevolg gehad het. Dit gaan uiteindelik om ' $n$ Goddelike ingrype in die ganse bestaan van die betrokke individu en dit het implikasies vir die geestelike maar ook die emosionele en fisiese dimensies. Hierdie wedersydse beïnvloeding en wisselwerking is dan ook veral die fokus van hierdie artikel.

Iets van hierdie selfde wisselwerking wil ook deurskemer in die verskillende vertalings van die volgende twee Skrifgedeeltes. 
Spreuke 17:22:

- “'n Vrolike mens is 'n gesonde mens, 'n neerslagtige mens raak uitgeput” (NAB 1983).

- "n Opgeruimde geaardheid is goed vir die gesondheid, maar as 'n mens neerslagtig is, maak dit jou siek” (Die Lewende Bybel 1982).

- “A cheerful heart does good like medicine, but a broken spirit makes one sick” (The Living Bible 1997).

Spreuke 18:14:

- “As 'n mens liggaamlik siek is, kan 'n gesonde gees jou opbeur, maar as jou gees geknak is, hoe sal jy weer moed kry?” (Lewende Bybel 1982).

- "Your will to live can sustain you when you are sick, but if you lose it, your last hope is gone" (Holy Bible, Good News Edition 1984).

- “A man's courage can sustain his broken body, but when courage dies, what hope is left?” (The Living Bible 1997).

In hierdie gedeeltes is daar dan ook iets waar te neem van die feit dat die mens ' $n$ eenheidswese is en dat probleme binne een dimensie van hierdie persoon ook ' $n$ invloed op ander dimensies van hierdie selfde persoon kan hê.

\section{HISTORIESE AANLOOP}

Die beginsel van die mens as ' $n$ eenheidswese is nie ' $n$ nuwe gedagte nie. Backus (1998:14) wys in hierdie verband op die volgende voorbeelde:

- Plato en Sokrates, wat ongeveer 500jr vC geleef het, het reeds die denke/liggaam verbintenis waargeneem en gewys op die belangrikheid hiervan met betrekking tot siekte.

- Hippocrates, die vader van medisyne, het gesê dat hy eerder sou verkies om te weet watter tipe persoon ' $n$ siekte het as watter soort siekte die persoon het.

- Galen, 'n belangrike Griekse medikus wat ongeveer $140 \mathrm{nC}$ geleef het, het alreeds geskryf oor die moontlike verhouding tussen depressie en borskanker wat hy waargeneem het. 
- Sir William Osler, ' $\mathrm{n}$ briljante medikus en ook mediese geskiedskrywer, het gesê dat die uiteindelike verloop van tuberkulose baie meer te doen het met dit wat in die binneste van die pasiënt aan die gang is as wat dit noodwendig te doen het met die toestand van die pasiënt se longe.

\section{DIE CARTESIAANSE DUALISME}

'n Aspek wat deur verskeie navorsers (Lynch 1985:160; Wylie 2004:16; Pert 2003:18; Quinlan 2006:4) uitgewys word as een van die aanleidende oorsake tot die kunsmatige skeiding tussen liggaam en denke, is die sogenaamde Cartesiaanse dualisme. Dit dateer terug na die tydperk van die Renaissance. Die heersende standpunt was dat die wêreld basies bestaan uit twee sfere. Die een is die fisiese en materiële wat wetenskaplik gemeet kan word. Die ander een is die geestelike, die spirituele wêreld, dit wat ' $n$ refleksie van die menslike siel is en wat nie gemeet kan word nie. Die wetenskap het gevolglik voluit gefokus op die wêreld van dinge en objekte en die geestelike dimensie van die denke en van emosies oorgelaat aan die godsdiens en die filosofie. Gegewe hierdie dichotomie tussen die denke en materie, tussen wetenskap en godsdiens, was dit onvermydelik dat ook die mediese wetenskap (en aanverwante dissiplines) dieselfde onderskeid sou tref. Daar is vervolgens veel meer gefokus op die 'werklike' organies-fisiese oorsake van menslike siekte. "For 350 years medical science ignored relationships between emotions and physical illness because science ignored the study of emotions (since emotions were a reflection of the human soul) and instead focused exclusively on the physical causes of disease” (Lynch 1985:160).

Die rol van iemand soos René Descartes (1596-1650), filosoof en grondlegger van moderne geneeskunde, met betrekking tot die skeiding tussen liggaam en denke was redelik deurslaggewend (vandaar dan ook die verwysing na die Cartesiaanse dualisme). Hy het die denke beskou as 'n nie-materiële substans en vandaar dan die skeiding met die liggaam wat wel materieël is. Pert (2003:18) verwys selfs na ' $n$ ooreenkoms wat Descartes met die destydse Pous sou aangegaan het dat hy niks te doen sou hê met die area van die siel, denke en emosies nie, en dat die mens vervolgens vir die twee eeue daarna in twee verdeel was. Een van die gevolge van hierdie 
gebeure word deur Wylie (2004:16) soos volg geformuleer: "The West's infatuation with Cartesian dualism has made our bodies somehow strange to us, a self-alienation reinforced by clinical psychology”. Die uitdaging is tans egter, veral ook aan die pastoraat, om weer hierdie twee sfere te integreer.

\section{5 'N NUWE STUDIEVELD}

Tot ' $n$ aantal jare gelede was mediese bioloë vas oortuig dat die brein en die denke geen invloed uitoefen op die immuun sisteem nie laasgenoemde was veronderstel om vir homself te 'dink'. Die kommunikasie binne die immuun sisteem sou dan ook binne 'n geslote netwerk plaasvind waar daar slegs gekommunikeer is met verskillende komponente binne die sisteem self (Backus 1998:63). Navorsing deur onder andere Candace Pert (2003), wat hoof is van die afdeling oor brein biochemie aan die National Institute of Mental Health in die VSA, het hierdie teorie egter verkeerd bewys. Dit het ook die weg gebaan vir die totstandkoming van 'n nuwe dissipline waarvan die benaming ' $n$ sterk aanduiding is van die invloed wat die denke uitoefen met betrekking tot die immuunsisteem: psigo-neuroimmunologie.

Met betrekking tot psigoneuroïmmunologie was daar in 1985 nog geen inskrywings onder Medline, die grootste mediese databasis. Tussen 1995 en 1997 was daar egter reeds meer as 100 publikasies aangedui, en sedertdien het die getal dramaties toegeneem (Quinlan 2006:14). Candace Pert (2003: 25) se pioniers navorsing het onteenseglik aangetoon dat daar ' $n$ biochemiese verbintenis bestaan tussen die denke en die liggaam. Sy het in hierdie verband aangetoon dat daar reseptore vir neuropeptides aanwesig is in die selle van die immuun sisteem. Neuropeptides is chemikalieë wat deur die brein geproduseer word na gelang van wisselende emosies. Die resultate van hierdie navorsing dui op die basiese feit dat die immuun sisteem fyn ingestem is op die 'gesprek' wat binne die denke plaasvind.

\section{1 'n Paradigma skuif}

Met betrekking tot die liggaamlike en geesteswelsyn van die mens is die biofisiese (of biomediese of biomeganiese) paradigma besig om uit te faseer ten gunste van die sogenaamde biopsigososiale model (Backus 1998:94; Ray 2004:29). Laasgenoemde benadering se 
uitgangspunt berus op die navorsing soos reeds aangedui. Dit kom daarop neer dat die oorsake, ontwikkeling en afloop van 'n siekte bepaal word deur die interaksie tussen enersyds psigologiese, sosiale en kulturele faktore, en andersyds biochemie en fisiologie. Ray (2005:30) haal die resultate aan van ' $n$ ondersoek met betrekking tot pasiënte by mediese klinieke, wat daarop dui dat slegs $16 \%$ van hierdie persone se probleme verklaar kon word met behulp van die tradisionele biofisiese paradigma. Aansluitend hierby is ook die statistieke wat gegee word deur die psigiater, Paul Meier, wat aan die hoof staan van die 28 Meier klinieke in die VSA. Die klinieke word bedryf op ' $n$ Christelike basis en elke kliniek het 'n multidissiplinêre span wat ' $n$ holistiese benadering volg. Meier et al (2005:130) sê dat indien hulle bloot medikasie aan hul kliënte gee, dan ervaar hulle slegs ' $n$ 30\% verbetering na twee tot drie weke. Diegene wat egter medikasie sowel as pastorale berading ontvang, toon ongeveer 50\% verbetering na dieselfde tydperk.

Wylie (2006) wys op die feit dat verskeie dissiplines alreeds die afgelope 30 jaar besig is met navorsing rondom die liggaam/ denke verbintenis. Dit was veral dan ook trauma spesialiste soos onder andere Bessel van der Kolk (1994) se navorsing om die onderskeie velde van neurobiologie en trauma te kombineer, wat 'n groot bydrae gelewer in die ontginning en oopmaak van hierdie nuwe veld.

\subsection{Die liggaamsgeheue (body memory)}

Met betrekking tot onverwerkte trauma asook die impak daarvan op die liggaam, word die aspek van 'liggaamsgeheue' raak verwoord deur Peter Levine (soos aangehaal deur Wylie 2004:12): “Trauma is locked in the body and it is in the body that it must be accessed and healed".

Fredrickson (1992:93) onderskei vyf verskillende vorme van geheue waarvan liggaamsgeheue een is. Die mens se liggaam reageer op enigiets wat met hom/haar gebeur, en in hierdie opsig is liggaamsgeheue gewoonlik dan ook ' $n$ fisiese manifestasie van ' $n$ onverwerkte insident uit die verlede. Hoe meer betekenisvol die insident, hoe groter die impak op die liggaam. Wat die brein ervaar, word in ' $n$ sekere sin ook deur die res van die liggaam ervaar (Ziegler 2002:47, 53). 
In haar boek, The body remembers, onderskei Rothschild (2000:28) tussen eksplisiete en implisiete geheue. Dit is dan veral met betrekking tot laasgenoemde dat ontstellende liggaamlike sensasies soms beleef word wanneer ' $n$ liggaamsgeheue geaktiveer word. Hierdie tipe geheue funksioneer vanuit die kommunikasie netwerk van die liggaam se senuweestelsel en wat dan daartoe lei dat waar die bewustelike denke soms sekere traumatiese gebeure in die verlede sou vergeet het, die liggaam dit wel onthou het.

In een van die klassieke werke rondom trauma berading, Trauma and recovery, gee Judith Herman $(1997: 45,167)$ 'n goeie voorbeeld van liggaamsgeheue. Dit gaan oor ' $n$ vrou wat as kind deur haar pa gemolesteer is. Later jare ervaar sy ' $n$ rugprobleem wat so ernstig geraak het dat ' $\mathrm{n}$ operasie beplan is. Sy ontvang egter berading wat uitloop op dramatiese verbetering. Dit blyk ook dat wanneer sy verwaarloos of kwaad gevoel het of selfs weer haar ouerhuis besoek het, die probleem vererger het.

\subsection{Onverwerkte emosies kan liggaamlike probleme veroor- saak}

Minirth en Meier (1990:16) wys op die feit dat stres oor die algemeen geneig is om ' $\mathrm{n}$ liggaamlike toestand te skep waar siektes maklik ' $n$ houvas kan kry. Dit kan byvoorbeeld lei tot ' $n$ verskeidenheid van psigofisiologiese siektes soos maagsere, dikdermontsteking en hoë bloeddruk. Stres kan ook daartoe lei dat die tempo waarteen die liggaam herstel na ' $n$ aansteeklike siekte of chirurgie, vertraag word.

Ray (2004:34) wys op verskeie studies wat die positiewe korrelasie aantoon tussen intense stres en die verhoogde moontlikheid van infeksie in die boonste lugwegkanale. Schorr (2005:4) maak melding van navorsing by die Universiteit van Leeds wat aantoon dat in gevalle van persone met chroniese uitputting, daar ' $n$ nege keer groter kans is dat hulle stresvolle gebeure en krisisse ervaar het gedurende die drie maande voor die aanvang van die siekte, as wat die geval is met gesonde persone.

\subsubsection{Angs}

Die mediese navorser, James Lynch (1985:105), wys op 'n navorsingsprojek deur die Mediese Skool by die Cornell Universiteit 
in die VSA. Uit onderhoude en toetse met 12 hartpasiënte het geblyk dat angs by 11 van die 12 'n baie prominente rol vervul het. Met betrekking tot al 12 het geblyk dat die aanvang van die fisiese probleem direk voortgespruit het uit ' $n$ spesifieke interpersoonlike traumatiese insident in die pasiënt se lewe.

\subsubsection{Gevoelens van verwerping}

Lynch (1985:133) wys in hierdie verband op die navorsing deur twee medici, William Schottstaedt en Stewart Wolf, by die hospitaal van die Oklahoma Mediese Skool, aangaande die invloed van interpersoonlike aksies op die vlakke van serum cholesterol. ' $n$ Voorbeeld word aangehaal van iemand wat as gevolg van intense verwerping deur sy vriendin geweldig depressief geraak het - sy serum cholesterol vlakke het gestyg en die volgende dag het hy ' $n$ hartaanval gehad en vier dae later is hy oorlede.

\subsubsection{Onverwerkte emosies sedert kinderjare}

Volgens Ziegler (2002:48) het navorsing 'n deurslaggewende verbintenis gelê tussen trauma tydens die kinderjare, en fisiese versteurings tydens die latere jare as volwassene.

Hierdie aspek word ook bevestig deur die mediese navorser, Vincent Felitti (2002). Deur die loop van een jaar is evaluasies gemaak van die 50,000 volwasse lede van die Kaiser Foundation Health Plan in San Diego. Die studie het huidige volwasse gesondheidstatus vergelyk met agt kategorieë van traumatiese ervarings tydens kinderjare. Ongeveer helfte van die deelnemers het een of meer van die 8 kategorieë vroeër in hul lewe beleef. Verder was 1 uit 4 blootgestel aan 2 kategorieë van misbruik en 1 uit 16 blootgestel aan 4 kategorieë van misbruik. Gedetaileerde onderhoude met 200 van hierdie persone wat ' $\mathrm{n}$ probleem het met vetsug/oorgewig het byvoorbeeld aangetoon dat misbruik tydens kinderjare baie algemeen was. ' $n$ Verdere gevolgtrekking vanuit hierdie studie is dat daar ' $n$ groot korrelasie is tussen verskillende vorme van huidige verslawing en vroeëre traumatiese lewenservaringe. Aan die einde van die projek het Felliti tot redelik ingrypende gevolgtrekkings gekom. Volgens hom word daar oor die algemeen met betrekking tot gesondheidsorg meer gefokus op die tersiêre gevolge ver stroomaf die werklike primêre aangeleenthede (soos onder andere onverwerkte trauma en stres uit die kinderjare) word goed beskerm deur sosiale 
konvensie en taboe. As gevolg van hierdie faktore word daar in die normale behandelingsproses oor die algemeen primêr gefokus op die kleinste deel van die probleem, te wete daardie deel waarmee die medikus gemaklik is en waar daar bloot maar net medikasie voorgeskryf kan word.

In hierdie selfde verband wys Lynch (1985:80) op navorsing (wat oor twee dekades gestrek het) wat bevestig dat daar 'n sterk verband bestaan tussen die verlies van 'n ouer op 'n vroeë ouderdom, en die latere ontwikkeling van ' $\mathrm{n}$ verskeidenheid van liggaamlike kwale. Daar is byvoorbeeld gevind dat ' $n$ beduidende getal van vaders van koronêre pasiënte voortydig gesterf het gewoonlik wanneer die seun êrens tussen die ouderdom van 5 - 17jr oud was.

\subsection{Die immuun-sisteem}

Quinlan (2006:7) wys op die noue chemiese koppeling wat bestaan tussen die emosies, wat alle vorme van stres insluit - goed of sleg, en die beheer sisteme van die endokriene en immuniteit stelsels deur middel van die sentrale senuwee stelsel. In die lig hiervan beklemtoon hy die belangrikheid van uiting te gee aan emosies op gepaste verbale en fisiese wyses. Indien dit nie gebeur nie dan kan dit lei tot die oormatige afskeiding van epinefrien, wat weer lei tot ' $n$ chemiese disfunksie, wat lei tot die verswakking van die immuun sisteem, asook 'n verhoogde potensiaal tot siekte (vergelyk ook Backus 1998:78).

\subsubsection{Die HPA aslyn en stres hormone}

Die sogenaamde HPA aslyn (hipotalamus, pituïtêre en adrenalien kliere) vervul ' $n$ belangrike skakel in die liggaam/denke verbintenis (Rothschild 2000:9; Retief 2004:33). Wanneer trauma of stres ervaar word dan stuur die amigdala boodskappe deur aan die res van die brein en dit aktiveer hierdie drieledige aslyn. Nadat die trauma verby is en/of die veg-of-vlug reaksie suksesvol afgeloop het, sal die kortisol (wat deur die adrenalien kliere afgeskei is) die alarm reaksie beëindig asook die produsering van epinefrien/ norepinefrien, ten einde die liggaam te help om weer homeostasis te herstel. In die geval van post traumatiese stres versteuring (PTSV) loop daar egter iets verkeerd binne hierdie HPA aslyn wat verband hou met die feit dat die adrenalien kliere nie genoeg kortisol afskei om die alarm 
reaksie te beëindig nie. Volgens Rothschild (2000:9) het verskeie studies in hierdie verband aangetoon dat persone met PTSV, laer vlakke van kortisol het as in die geval van kontrole groepe.

\subsection{Siektes}

Die mediese wetenskap is reeds vir baie jare bewus van die feit dat aspekte soos voldoende oefening, fiksheid, rus en die regte voeding almal bydra om die aftakelende invloed van stres teë te werk. Daar is selfs navorsingsresultate wat daarop dui dat die immuunsisteem asook ' $n$ persoon se kapasiteit om sekere siektes soos byvoorbeeld kanker te weerstaan, positief beïnvloed kan word deur korrek te oefen, reg te eet en stres uit te skakel (Minirth \& Byrd 1994:71).

\subsection{Kritiese lewensveranderinge}

Oor die jare is daar heelwat navorsing gedoen met betrekking tot die invloed van kritiese lewensveranderinge op die mens se gesondheid. Adolph Meyer was in 1948 die eerste om 'n lys op te stel van stresvolle faktore in die alledaagse lewe. Daarna het die lys van Harold Wolff (1950) gevolg na aanleiding van sy werk in Indië (Smith 1998:5). Een van die belangrikste studies rondom stres navorsing het egter in 1967 verskyn deur Holmes en Rahe, waarin hulle voortgebou het op die bydraes deur Meyer en Wolff. Hulle het ' $n$ lys opgestel van 43 van die mees algemene stres situasies wat die gemiddelde persoon êrens mag beleef. Aan die hand hiervan is ' $n$ formule uitgewerk waarvolgens daar met groot waarskynlikheid 'voorspel' sou kon word dat die betrokke persoon psigiese of fisiese probleme in die toekoms sou ervaar indien hy/sy binne die bestek van een jaar te veel blootstelling gehad het aan enige van die 43 potensiële stres situasies.

Sedertdien het duisende artikels rondom hierdie tema verskyn en is daar ook heelwat meer verfyning en variasies toegepas met betrekking tot die oorspronklike skaal van Holmes en Rahe (vgl in hierdie verband byvoorbeeld Cohen 2000; Wismer 2000:246; Smith 1998:26).

Waaroor daar egter redelike eenstemmigheid in die navorsing rondom hierdie kwessie is, is dat aspekte soos die volgende redelik bepalend is met betrekking tot die verhouding tussen sekere gebeure en die daaropvolgende versteurings: 
- Die ongewensde;

- Die onvoorspelbare;

- Die onkontroleerbare;

- Die omvang van die gebeure;

- Die verskeidenheid van gebeure binne 'n sekere tydsfase (time clustering - Smith 1998:26).

\subsection{Die rol van genetika}

Volgens Meier et al (2005:31) het 50\% van persone 'n genetiese geneigdheid tot geestesgesondheidsprobleme. In hierdie verband speel die volgende vier chemiese bestanddele in die brein ' $n$ uiters belangrike rol: serotonien, norepinefrien, dopamien en GABA (gamma-amino butyric acid). Faktore soos depressie, stres en trauma het oor die algemeen ' $n$ negatiewe invloed op die vlakke van hierdie vier bestanddele. Van hierdie vier beskou Meier en andere (2005:45) serotonien as die heel belangrikste chemiese bestanddeel van die liggaam. "Without adequate serotonin in our brains, we cannot even experience love, joy, peace, patience, gentleness, meekness, humility, self-control - the fruit of the Spirit.”

Hierdie navorsers toon verder aan dat $50 \%$ van persone ' $n$ hoër as gemiddelde geneigdheid het tot afplatting van serotonien vlakke as gevolg van stres Meyer et al (2005:57). Verder is dit ook so dat hartseer en woede wat innerlik opgekrop word, bydra tot die afplatting van serotonien in die brein, wat weer kan lei tot intense kliniese depressie. Die gevolgtrekking wat hieruit gemaak kan word is dat onverwerkte trauma uiters nadelig kan wees op die lang termyn aangesien dit hoë vlakke van stres impliseer asook in talle gevalle emosies soos hartseer en woede (vergelyk ook Van der Kolk, 1994:256).

\subsection{Die rol van wilskeuses}

Betreffende die noue verband tussen liggaam en denke wys Wright (2003:155) op die geval van 'n pasiënt by wie daar hartversaking was direk na ' $n$ operasie. Daar is hartmassering toegepas sonder enige welslae en alle ander pogings om die pasiënt se hart weer aan die gang te kry het ook misluk. Alhoewel die pasiënt nie by sy bewussyn was nie het die dokter met hom gepraat en gesê: "Ons het 
jou hulp nodig - ons kan nie jou hart weer aan die gang kry nie - sê vir jou hart om te begin klop”. Onmiddellik daarna het die pasiënt se hart normaal begin funksioneer.

Lynch (1985:152) wys op die geval van 'n professor in chirurgie ' $n$ aantal jare gelede by die John Hopkins School of Medicine, wat van mening was dat ' $\mathrm{n}$ persoon se wil om te lewe so belangrik is dat hy geweier het om enige pasiënt te opereer wat nie oortuig was dat hy/sy die operasie sou oorleef nie.

Kiecolt-Glaser et al (1984:14) verwoord ook iets van die belangrikheid van die regte wilskeuses en innerlike besluite met die volgende stelling: "You are the master of your immune system. There is no better cure for anything than a good attitude". Schorr (2005:1,6) sluit hierby aan wanneer hy sê dat "What you believe about your illness influences how sick you become... The initial injury of illness is almost irrelevant - what really matters is the interpretation and emotional reaction."

Volgens Ray (2004:32) gaan dit nie soseer oor die hanteringsmeganismes waaroor ' $n$ individu beskik of nie beskik nie - wat werklik saak maak is die innerlike oortuiging by hierdie persoon betreffende die hanteringsmeganismes waaroor hy beskik of nie beskik nie. Die bepalende faktor is dus die persepsie omtrent die situasie (vergelyk ook Backus 1998:40,78).

\subsection{Sosiale ondersteuning en alleenheid}

Ray (2004:36) wys op die resultate van 'n studie wat die verhouding ondersoek het tussen enersyds die omvang en aard van 'n persoon se sosiale netwerk, en andersyds die persoon se gesondheid en kanse om te sterf. Daar is veral op die volgende vier areas gefokus: huwelik, vriende en familie, kerklidmaatskap en betrokkenheid, en lidmaatskap van spesifieke groepe. Vrae wat hiermee verband hou, is aan 7,000 persone gestel en oor ' $n$ tydperk van nege jaar gemonitor. Nadat alle faktore in ag geneem is, het uiteindelik geblyk dat die waarskynlikheid dat iemand sou sterf gedurende die nege jaar, verband gehou het met die grootte van sy/haar sosiale ondersteuning sisteem. Die heel belangrikste faktor het geblyk die interaksie met familie en vriende te wees. 
Backus (1989:41) sluit hierby aan wanneer hy konstateer dat "When social contact is increased and loneliness is reduced the immune system seems to grow stronger and health and longevity get a boost”.

\subsection{Terapeutiese waarde van skryf of verbalisering}

In ' $\mathrm{n}$ nuusberig deur die BBC (2006) word gewys op die feit dat stres ' $n$ bepalende faktor is ten opsigte van die mate en die wyse van herstel na chirurgie. Verder word ook gewys op die resultate van navorsing wat die helende effek beklemtoon van emosies wat op papier verwoord is - dit lei tot vinniger heling van fisiese wonde aangesien dit bydra tot ' $n$ meer effektiewe funksionering van die immuun sisteem.

Dit korreleer dan ook met die navorsing deur James Pennebaker (1995:3) wat aantoon dat daar beterskap kan plaasvind ten opsigte van gesondheidsprobleme, wat die gevolg is van traumatiese ervarings, wanneer die betrokke individu sy/haar ervarings kan verbaliseer. In sy navorsing wys Pennebaker byvoorbeeld op sekere biologiese veranderinge wat plaasvind wanneer daar geskryf of gepraat word. Die subjektiewe wyse waarop ' $n$ persoon sy/haar emosies hanteer en interpreteer, kan dus ' $n$ direkte invloed op sy/haar gesondheid en sosiale gedrag hê. Verder is sy bevinding dat die onderdrukking van sodanige emosies onder andere kan lei tot hoofpyne en rugpyn (Pennebaker 1995:6).

\section{IMPLIKASIES VIR DIE PASTORAAT}

- Die pastoraat staan voor die uitdaging om die skeiding tussen liggaam en denke, wat met verloop van tyd al groter geword het, weer te oorbrug. In hierdie proses sal daar opnuut gefokus moet word op die Bybels benadering van die mens as ' $n$ eenheidswese. Hierdie eenheid tussen gees, siel en liggaam impliseer ' $n$ baie noue wisselwerking tussen die geestelike, emosionele en fisiese dimensies.

- Hiermee saam is daar ook ' $n$ behoefte om die biopsigososiale model verder uit te bou deur die inkorporering van die pastoraal/geestelike dimensie as ' $n$ bykomende kategorie. Die Meier klinieke in die VSA kan as ' $n$ voorbeeld dien van so ' $n$ holistiese, omvattende, multidissiplinêre benadering waar volle 
erkenning gegee word in die pastorale terapeutiese proses aan die interaksie tussen die liggaamlike (medies), geestelike (pastoraal) en siels- (emosies, wil en denke) (of psigologiese) dimensies. Dit is ook in lyn met ' $\mathrm{n}$ al groter bewuswording die afgelope aantal jare betreffende die besondere bydrae wat ' $n$ pastorale benadering kan lewer tot fisiese en geestes gesondheid.

Twenty years ago, spirituality and religion were fringe components in psychology and health care. Better questions, better methodologies, and a shift in the assumptions that underlie the behavioral sciences have brought spirituality (including religious beliefs) almost into the mainstream and certainly into our journals.

(Ray 2004:33)

Vergelyk in hierdie verband ook die volgende opmerking deur Scheurich (2003:356,360): “The role of spirituality in medical practice has sparked burgeoning interest in recent years... There is a need for a broad understanding of the roles of meaning and belief in training and education”.

Die noodsaaklike bydrae van die pastoraat met betrekking tot gesondheid is ook op ' $\mathrm{n}$ besondere wyse beklemtoon deur ' $\mathrm{n}$ reeks van artikels wat gepubliseer is in American Psychologist van Januarie 2003. Dit is geplaas onder 'n spesifieke kategorie met die titel, Spirituality, Religion, and Health (vergelyk Miller \& Thoresen 2003:24-35; Powell et al 2003:36-52; Seeman et al 2003:53-63; Hill \& Pargament 2003:64-74).

- 'n Aspek soos 'liggaamsgeheue' het uiteraard vir die pastoraat ingrypende implikasies. As gevolg van die noue wisselwerking tussen liggaam en denke is dit gevolglik sinvol om, met betrekking tot opvallende aanduidings van liggaamsgeheue, beradenes uit te vra ten opsigte van traumatiese ervarings wat moontlik hiermee verband mag hou. Indien sulke onverwerkte emosies deur gesprek en gebed asook ' $n$ proses van vergifnis hanteer sou word, kan dit oor die algemeen lei tot emosionele stabiliteit en heel dikwels ook tot die spontane opklaring van sekere fisiese simptome. Dit kan ook as besondere geloofsversterking dien vir iemand wat as gevolg van die omstandighede 
in diepe geloofsvertwyfeling vasgeval het (Seamands 2002: 139; Richardson 2005:151; Kraft 1994:42).

- Gevoelens van verwerping asook onverwerkte emosies sedert kinderjare het geblyk van besondere belang te wees (die dood van 'n ouer, misbruik, rouprosesse wat nooit afgehandel is nie, ens) met as moontlike latere uitvloeisels aspekte soos verslawing, vetsug, koronêre hartsiektes en kanker. Vanuit die pastoraat kan daar gevolglik gefokus word op al die vermelde areas ten einde seker te maak dat alle onafgehandelde emosionele en geestelike prosesse die nodige aandag kry. 'n Proses van kognitiewe herstrukturering met behulp van waarhede uit die Woord kan hier baie effektief toegepas word. By persone wat baie verwerping en emosionele aftakeling beleef het is daar gewoonlik kognitiewe leuens wat diep ingebed lê. 'n Vernuwing van denke aan die hand van gedeeltes soos byvoorbeeld Psalm 139:14; Romeine 8:37; 12:2; Efesiërs 1:6; 2:10 en 2 Korintiërs 12:9 kan gevolglik 'n bevrydende ervaring vir so ' $\mathrm{n}$ persoon wees (McDonald 1995:209; Backus 1998:95; Anderson et al 2000:153).

- Die innerlike onderdrukking van stresvolle emosies soos vrees, woede of bitterheid het geblyk die potensiaal te hê van die verswakking van die immuun sisteem met gevolglike verhoogde geneigdheid tot siekte. By sommige Christene is daar soms die opvatting dat gemelde emosies nie tuishoort by ' $n$ goeie Christen nie en gevolglik word dit onderdruk. Vanuit ' $n$ pastorale beradingsperspektief is dit daarom noodsaaklik om op die uitkyk hiervoor te wees en beradenes aan te moedig om alle vorme van ontkenning te vermy.

- Die psigologiese ingesteldheid van ' $n$ persoon op liggaamlike probleme en siektes het geblyk 'n groot invloed uit te oefen ten opsigte van die uiteindelike verloop daarvan. In die pastorale begeleiding van sulke persone kan hulle aangemoedig word om opbouende en positiewe gedeeltes vanuit die Woord te memoriseer en daaroor te mediteer. Backus (1998:94) gee 'n aantal sinvolle riglyne in hierdie verband (vergelyk ook Anderson et al 2000:305). 
- Innerlike wilskeuses en besluite kan van deurslaggewende belang wees met betrekking tot liggaamlike en geestes gesondheid. Pastorale begeleiding en motivering (veral ook voor operasies) kan hier van besondere waarde wees.

- Betreffende die kardinale rol van 'n ondersteuning sisteem en sosiale netwerk kan die kerk en kleingroepe oor die algemeen ' $n$ deurslaggewende bydrae lewer. Alleenheid en isolasie kan emosioneel, geestelik en fisies aftakelend wees en pastorale insette ten einde hierdie probleem die hoof te bied, kan bydra tot heling asook beter lewenskwaliteit.

- Oor die algemeen kan daar binne die pastoraat heelwat meer geleentheid ingerig word ten einde die terapeutiese waarde (emosioneel en fisies) van skryf of verbalisering ten volle te benut - iets van dit wat deur die volgende stelling van Rothschild (2000:173) verwoord word: "Language bridges the mind/body gap, linking explicit and implicit memories."

- As ' $n$ treffende voorbeeld in hierdie verband kan gewys word op ' $n$ artikel deur twee psigiaters, McAll en Wilson (1987) waarin hulle die resultate aanbied van hul navorsing met meer as 400 vroue wat aborsies ondergaan het en agterna, ondanks die standaard prosedures van psigiatriese en sielkundige behandeling, nie kon herstel van depressie asook ander emosionele wanbalanse nie. 'n Private nagmaalsdiens vir elk van die onderskeie families was uiteindelik deel van die pastoraal-terapeutiese benadering waarop toe besluit is. Tydens die betrokke nagmaalsgeleenthede is onder andere heelwat geleentheid ingeruim vir verbalisering van emosies en die neem van afskeid (closure). Volgens hierdie psigiaters het dit uitgeloop op bykans onmiddellike verligting van die hartseer en in meeste gevalle ook die opklaring van alle ander simptome by die betrokke pasiënt.

\section{GEVOLGTREKKING}

Die belangrikheid van die mens as ' $n$ eenheidswese (liggaam, gees en siel) het baie sterk in hierdie artikel na vore gekom. Teen die agtergrond hiervan is daar vervolgens gefokus op die historiese aanloop en vertrekpunte van die biopsigo-sosiale model. Dit het geblyk dat die pastoraat ' $n$ besondere bydrae kan lewer in die 
verdere komplimentering en uitbou van laasgenoemde model. In hierdie verband is ' $n$ pleidooi dan ook gelewer vir die inkorporering van die pastorale/geestelike dimensie. Die beradene sal dan inderdaad op ' $n$ holistiese wyse benader kan word met die nodige insette vanuit elke tersaaklike dissipline, tot uiteindelike heling en genesing.

\section{Literatuurverwysings}

Anderson, N T, Zuehlke T E \& Zuehlke J S 2000. Christ centered therapy. Grand Rapids, Michigan: Zondervan Publishing House.

Backus, W 1998. The healing power of a Christian mind. Minneapolis: Bethany House Publishers.

BBC News 2006. Written words help wounds heal. http://news.bbc.co.uk/go/pr/ fr/-/2/hi/ health/3081746.stm Datum van gebruik: 9/1/06.

Cohen S 2000. Measures of psychological stress. http://www.macses.ucsf.edu/ Research/Psychosocial/notebook/stress.html. Datum van gebruik: 6/2/06

Die Lewende Bybel 1982. Christelike Uitgewersmaatskappy: Roodepoort.

Die Nuwe Afrikaanse Bybelvertaling (NAB) 1983. Kaapstad: Bybelgenootskap van Suid-Afrika

Felitti, V J 2002. The relation between adverse childhood experiences and health: turning gold into lead. http://www.kaiserpermanente.org/medicine/ permjournal/winter02/goldtolead.html. Datum van gebruik: 12 Nov. 2002.

Fredrickson, R 1992. Repressed memories. New York: Simon \& Schuster.

Herman, J L 1997. Trauma and recovery. USA: Basic Books.

Hill, P C \& Pargament, K I 2003. Advances in the conceptualization and measurement of religion and spirituality: implications for physical and mental health research. American Psychologist 58/1, 64-74.

Holmes, T H \& RAHE, R H 1967. The social readjustment rating scale. Journal of Psychosomatic Research 11, 213-218.

Holy Bible 1984. Good News Edition. Today’s English Version. Bible Society of South Africa: Cape Town.

Kiecolt-glaser J K, Garner W, Speicher C E, Penn G \& Vlaser R 1984. Psychococial modifiers of immunocompetence in medical students. Psychosomatic Medicine 46/1, 7-14.

Kraft, C H 1994. Deep wounds, deep healing. Ann Arbor, Michigan: Servant Publications.

Louw, J P \& Nida, E A 1988. Greek-English lexicon of the New Testament based on semantic domains. 2 vols. New York: United Bible Societies.

Lynch, J J 1985. The broken heart. The medical consequences of loneliness. New York: Basic Books, Inc., Publishers. 
McAll, K \& Wilson, W P 1987. Ritual mourning for unresolved grief after abortion. Southern Medical Journal 80/7, 817-821.

Mcdonald, A N 1995. Repressed memories. Can you trust them? Grand Rapids, Michigan: Fleming H. Revell.

Meier, P, Clements, T, Bertrand, J \& Mandt, D 2005. Blue Genes. Wheaton, Illinois: Tyndale.

Miller, W R \& Thoresen, C E 2003. Spirituality, religion, and health: an emerging research field. American Psychologist 58/1, 24-35.

Minirth, F B \& Byrd, W 1994. Christian Psychiatry. Grand Rapids, Michigan: Fleming H.Revell.

Minirth, F B \& Meier, P D 1990. Counseling and the nature of man. Grand Rapids, Michigan: Baker Book House.

Pennebaker, J W 1995. Emotions, disclosure, and health. Washington, DC: American Psychological Association.

Pert, C 2003. Molecules of emotion. The science behind mind-body medicine. New York: Scribner.

Powell, L H, Shahabi, L \& Thoresen, C E 2003. Religion and spirituality: linkages to physical health. American Psychologist 58/1, 36-52.

Quinlan, J 2006. Psychoneuroimmunology. http://nfnlp.com/psychoneuroimmunology_quinlan. htm Datum van gebruik: 12 Jan. 2006.

Ray, O 2004. How the mind hurts and heals the body. American Psychologist $59 / 1,29-40$.

Retief, Y 2004. Genesing vir trauma in die Suid-Afrikaanse konteks. Kaapstad: Struik Christelike Boeke.

Richardson, R 2005. Experiencing healing prayer. Downers Grove, Illinois: InterVarsity Press.

Rothschild, B 2000. The body remembers. The psychophysiology of trauma and trauma treatment. New York: W.W.Norton \& Company.

Seamands, D A 2002. Healing for damaged emotions. Colorado Springs: Cook Communications Ministries.

Seeman, T E, Dubin, L F \& Seeman, M 2003. Religiosity/spirituality and health: a critical review of the evidence for biological pathways. American Psychologist 58/1, 53-63.

Scheurich, N 2003. Reconsidering spirituality and medicine. American Medicine 78, 356-360.

Schorr, M 2005. Is it all in my head? Psychology Today Magazine, May/June, 1-9.

Smith, J C 1998. Understanding stress and coping. New York: Macmillan Publishing Company.

The Living Bible 1997. Wheaton, Illinois: Tyndale House Publishers, Inc. 
Van der Kolk, B 1994. The body keeps the score. Harvard Review of Psychiatry 1/5, 253-265.

Wismer, L S 2000. Grief and loss, in: Anderson, N T, Zuehlke, T E \& Zuehlke, J S (eds), Christ centered therapy, 243-249. Grand Rapids, Michigan: Zondervan Publishing House.

Wright, H N 2003. The new guide to crisis and trauma counseling. A practical guide for ministers, counselors and lay counselors. Ventura, California: Regal Books.

Wylie, M S 2004. The limits of talk. Bessel van der Kolk wants to transform the treatment of trauma. Psychotherapy Networker 28/1, 1-17.

-, 2006. Beyond talk. Using our bodies to get the heart of the matter. http://www.psychotherapynetworker.com/jf04_wylie.htm Datum van gebruik: 9 Jan. 2006.

Ziegler, D 2002. Traumatic experience and the brain. Phoenix, Arizona: Acacia Publishing, Inc. 